\title{
DECENTRALIZED ADMINISTRATIVE LAW IN THE ORGANIZATION FOR ECONOMIC COOPERATION AND DEVELOPMENT
}

\author{
JAMES SALZMAN $*^{1}$
}

INTRODUCTION

When one thinks of international organizations whose administrative processes legal scholars should understand, the European Union and the World Trade Organization come to mind without a moment's hesitation. A bit later, perhaps, one might also come up with the Montreal Protocol secretariat, Codex Alimentarius, or the International Organization for Standardization. It will probably take a good while before the Organization for Economic Cooperation and Development (OECD) comes to mind. In some respects this is hardly surprising, for the OECD is neither a well-known nor well-studied international organization (and is certainly not known as a lawmaking institution). Located in Paris and best known for its research reports, the OECD has a "secret life" that goes well beyond that of policy analysis. Indeed, a number of its activities influence domestic agency action far more than is generally realized.

The OECD provides a wonderful example for the study of global administrative law for the simple reason that it is a hybrid organization. Through its many diverse activities, the OECD shares characteristics with primarily lawmaking international bodies, such as the European Union, primarily standardsetting bodies, such as the World Health Organization, and primarily data gathering and research organizations, such as the U.N. Conference on Trade and Development. Perhaps surprisingly, there is no uniform administrative law in the OECD. In managing this constellation of activities, the OECD has chosen largely to decentralize its administrative law down to subject-specific director-

\footnotetext{
Copyright (c) 2005 by James Salzman

This Article is also available at http://law.duke.edu/journals/lcp.

* Professor, Duke School of Law \& Nicholas School of the Environment and Earth Sciences. The author is grateful for the invitations of Dick Stewart and Benedict Kingsbury to examine this issue, the helpful insights provided by participants in the NYU workshop, and the comments of David Trubek. This piece could not have been written without interviews with the OECD secretariat. In the interests of candor, I have not attributed specific quotes to secretariat staff, though the law review editors have reviewed my interview notes. I worked in the OECD Environment Directorate from 1990-1992.

1. Some of the background information in this article has been previously published in James Salzman, Labor Rights, Globalization, and Institutions: The Role and Influence of the Organization for Economic Cooperation and Development, 21 MICH. J. INT'L L. 769 (2000).
} 
ates who develop administrative procedures on an ad hoc basis. Thus, in studying administrative law at the OECD, one is effectively studying multiple administrative law systems under one roof.

This article commences with a description of the OECD. Since the organization does not garner much attention from scholars or the public, Section II describes the organization's origins and operations, and offers examples of its activities. Section III then provides four case studies that examine the OECD's multiple roles and how these bear on the development of the organization's administrative law. The cases range from traditional treaty-making, to consensus development of standards, to quasi-judicial review of the actions of multinational enterprises. Each of these examples relies on different types of administrative mechanisms to address the core concerns of transparency, responsiveness, and accountability. The concluding section builds off of these case studies, exploring whether administrative law safeguards should apply to OECD activities that, while not lawmaking themselves, exert important influence on domestic lawmaking and underscores why the OECD has adopted a decentralized model of administrative law.

II

\section{THE ORGANIZATION FOR ECONOMIC COOPERATION AND DEVELOPMENT}

\section{A. History of the OECD}

The predecessor to the OECD, the Organization for European Economic Cooperation (OEEC), was created in April 1948, amidst the rubble of World War II's devastation. The OEEC's explicit charge was to administer the Marshall Plan for the reconstruction of Europe. Housed in the Chateau de la Muette in Paris with representatives from its founding eighteen member countries, the OEEC's name expressed well the organization's goals - the promotion of cooperation and commerce among Europe's reconstructed economies, the development of a European customs union, and, ultimately, a free trade area. The OEEC's initial work focused on the effective allocation of the Marshall Plan's grants and credits. With the unexpected end of Marshall Plan aid in 1952, the OEEC remained active by directing its energies to European economic development and thus helping lay the groundwork for the creation of the European Economic Community.

With the establishment of the European Economic Community in 1957, the original impetus for creation of the OEEC no longer existed. Europe now had a permanent institution dedicated to forging closer economic ties. Member countries had found value in the common forum provided by the OEEC, however, and the Cold War's ideological battle over centrally-controlled versus market economies had grown considerably colder and more hostile. Thus, the OEEC member countries decided to create a new organization in its place-the Organization for Economic Cooperation and Development (OECD). 
In keeping with its predecessor's mandate, the OECD is foremost an economic organization dedicated to the principles of market economies, economic growth, and world trade. ${ }^{2}$ The OECD's original membership of twenty-one countries (the founding Western European members, the United States, Canada, and key NATO allies Turkey and Iceland) has expanded to thirty today. ${ }^{3}$ The only legal requirement for membership, apart from unanimous approval of existing members, is for an applicant to have a market-based economy.

\section{B. OECD Activities}

In comparison with other international governmental organizations (IGOs), the OECD remains a curious creature. Far from being a Cold War relic, the OECD has developed into an amalgam of a rich man's club, a management consulting firm for governments, and a legislative body.

The OECD is, primarily, an exclusive club whose members produce twothirds of the world's goods and services. ${ }^{4}$ The OECD provides a private setting for wealthy industrialized governments to share experiences, identify issues of common concern, and coordinate domestic and international policies. In simple terms, the OECD's range of standing inter-governmental committees serves as useful "talking shops" for countries to share experiences, learning from one another's successes and challenges. The OECD occupies a unique position in the constellation of IGOs, with membership broader than the E.U., Nordic Council, or NAFTA, yet much more restrictive than the U.N. or WTO, with topic cover-

2. Its founding treaty mandates the organization to promote policies designed:

(a) to achieve the highest sustainable economic growth and employment and a rising standard of living in Member countries, while maintaining financial stability[ ] and thus to contribute to the development of the world economy[;]

(b) to contribute to sound economic expansion in Member as well as non-member countries in the process of economic development; and

(c) to contribute to the expansion of world trade on a multilateral, non-discriminatory basis in accordance with international obligations.

See Convention on the Organisation for Economic Co-operation and Development, Dec. 14, 1960, art. 1, 14-15, 12 U.S.T. 1728.

3. The Member countries and dates of accessions are: Australia (1971), Austria (1961), Belgium (1961), Canada (1961), Czech Republic (1995), Denmark (1961), Finland (1969), France (1961), Germany (1961), Greece (1961), Hungary (1996), Iceland (1961), Ireland (1961), Italy (1962), Japan (1964), Korea (1996), Luxembourg (1961), Mexico (1994), The Netherlands (1961), New Zealand (1973), Norway (1961), Poland (1996), Portugal (1961), Slovak Republic (2000), Spain (1961), Sweden (1961), Switzerland (1961), Turkey (1961), United Kingdom (1961), United States (1961). Ratification of the Convention of the OECD, available at http://www.oecd.org/document/58/0,2340,en_2649_ 201185_1889402_1_1_1_1,00.html.

4. http://www.oecd.org/document/18/0,2340,en_2649_201185_2068050_1_1_1_1,00.html. 
age as broad as any IGO. As a result, the OECD provides a restricted forum on virtually unrestricted topics. ${ }^{5}$

The OECD also acts as a high-powered research institution. The organization's more than 1,800 employees (many of whom are economists) collect data, monitor trends, forecast economic developments, and develop policy options for consideration by member countries. The OECD's ability to gather and synthesize data on members' policy initiatives and results provides a wealth of insight concerning which types of policies work best in particular settings. The result is over two hundred and fifty books published annually (in addition to the many reports that are not published). ${ }^{6}$

Bringing together the wealthy industrialized nations in a private setting and providing high-powered research has led in a number of instances to negotiation and adoption of international legal instruments. Article 5 of the OECD's convention provides for member countries, through the Council of Ministers, to take three types of legal action-Recommendations, Decisions, and agreements with other governmental bodies.

Recommendations are non-binding agreements that generally represent policy advice with a strong base of support. Member countries generally use Recommendations either as a means to influence domestic policy development, arguing in their respective capitals that the OECD has endorsed a particular approach, or as a precursor to a Decision. It is rare for a Recommendation to lead to direct changes in agency action or rulemaking. As a recent example, in response to the increasing use of information technology to create new avenues for offshore investment for the purposes of tax avoidance and evasion, in 1998 the OECD Council adopted "two Recommendations to improve exchange of information between countries-advocating the use of tax identification numbers and a standard magnetic format for automatic exchange of information."

Decisions are binding on member countries. ${ }^{8}$ Not surprisingly, adoption of Decisions is less frequent than adoption of Recommendations, and the negotiations are followed much more closely by member countries. The OECD also

5. Perhaps one reason the OECD's mandate is so broad is its lack of direct political power authority, as described on the next page of text. As Lawrence Krause and Joseph Nye have observed, it is sometimes said that intergovernmental organizations operate according to "the law of inverse salience": the greater the political prominence of an issue, the less the operational autonomy of the organization. This law is sometimes used as a reason for limiting the scope of an organization's domain to a narrow range of issues that are more likely to be susceptible to technical than to broad political treatment. Lawrence B. Krause \& Joseph S. Nye, Reflections on the Economics and Politics of International Economic Organizations, 29 INT'L ORG. 323, 335 (1975)

6. Books and reports must be approved by all member countries prior to derestriction and publication. http://www.oecd.org/document/18/0,2340,en_2649_201185_2068050_1_1_1_1,00.html\#public.

7. OECD Ann. Rep. (1998), http://www.oecd.org/publications/97_rep/sec_gene1.htm.

8. While decisions are considered binding on member states and are expected to be implemented at the domestic level, there is no requirement for domestic ratification. Indeed, the OECD itself distinguishes between decisions and "internationally agreed instruments." http://www.oecd.org/about/ 0,2337,en_2649_201185_1_1_1_1_1,00.html. In terms of the hierarchy of international legal instruments, this would place OECD decisions at a level below treaties. 
occasionally serves as the negotiating forum for Internationally Agreed Instruments. These are essentially treaties or conventions.

Article 6 of the OECD Convention requires consensus for adoption of Recommendations and Decisions, though members may abstain and thereby enter the equivalent of a reservation. If proponents of a Recommendation or Decision face concerted opposition from even a few countries, a vote will not be taken until negotiation has produced a text unobjectionable to all the member countries. Although Decisions are binding, it is exceedingly rare for any OECD Decision to provide sanctions for noncompliance.

The OECD's work on bribery provides a useful example of Recommendations and Decisions at work, as well as the OECD's role as a rich man's club and management consultant. In 1975, the U.N. General Assembly adopted by consensus a resolution on "Measures against corrupt practices of transnational and other corporations, their intermediaries, and others involved." This led four years later to a draft convention on illicit payments. ${ }^{9}$ The draft convention was never adopted, however, because developing countries demanded adoption of stronger corporate codes as a precondition for their support. It took almost twenty years before the OECD addressed the issue directly. Following extensive discussions amongst member countries, the OECD adopted Recommendations in 1994, 1996, and 1997 on various aspects of bribery, calling on member countries to combat international corruption by making bribery of foreign public officials a crime, preventing tax deductions for bribes, prohibiting corruption in contracts funded by development assistance programs, and creating effective company rules on accounting and auditing to reveal practices of bribery. In December 1997, the member countries and five non-members agreed to a Decision that made binding the steps agreed to in previous Recommendations. ${ }^{10}$ Soon after, the U.N. adopted a declaration against bribery referring to the OECD and OAS Conventions and passed a code of conduct for public officials. ${ }^{11}$ This ability to reach agreement on issues that IGOs with larger membership have been unable to address meaningfully is a unique strength of the OECD.

In general, OECD recommendations and decisions tend to harmonize diverse practices, policies, and laws of its member countries. Whether the harmonization is generally upward or downward depends on the perspective of the particular member country. In the case of bribery, for example, the series of OECD recommendations were generally less than required in U.S. law but more than required by other countries.

9. Padideh Ala'i, The Legacy of Geographical Morality and Colonialism: A Historical Assessment of the Ongoing Crusade Against Corruption, 33 VAND. J. OF TRANSNAT'L L. 877, 913 n.163 (2000) (discussing the development of U.N. Doc. E/AC.67/L.1 (1979)).

10. Organization for Economic Cooperation and Development Convention on Combating Bribery of Foreign Public Officials in International Business Transactions, December 18, 1997, 37 I.L.M. 1, 4.

11. See generally Ala'i, supra note 9, at 910-18 (recounting the history of the influence of intergovernmental organizations on the U.N.'s adoption of standards for public officials regarding bribery). 
A last activity worth noting is less legal in nature, but likely more significant than recommendations or decisions: the OECD's central role in developing transgovernmental networks. Consider that the OECD's committees, working groups, expert groups, and conferences bring together approximately 40,000 government officials and experts annually. ${ }^{12}$ Professor Anne-Marie Slaughter goes so far as to predict that, in stark contrast to the United Nations' constellation of institutions, "[t]he next generation of international institutions is ... likely to look more like the Basle Committee [composed of twelve central bank governors], or, more formally, the Organization for Economic Cooperation and Development, dedicated to providing a forum for transnational problem-solving and the harmonization of national law." ${ }^{13}$

\section{OECD Structure}

Decisions and recommendations are voted on by the OECD Council, the governing body of member country representatives that oversees the work of the organization and meets twice monthly, and more if necessary. Representatives to the OECD Council are ambassador-level appointments, with one representative from each country as well as from the European Union. The OECD's productive work, however, is carried out by specialized directorates. Each directorate is governed by a managing committee composed of representatives from member countries. Committees, through a one-country one-vote process, determine the directorate's work program and priorities. Below the committees are divisions, groups, and ad hoc groups that oversee the more technical activities and the work program. As an example, the Environment Directorate's main committee, the Environmental Policy Committee, oversees divisions and working groups on waste management policy, transport, chemicals, pesticides and biotechnology, and other policy areas. In all, there are approximately two hundred committees, working groups and expert groups, involving the combined participation of thousands of senior officials from member country governments. Many individuals from academia, industry, and civil society participate as well, though primarily in the role of an issue-specific expert or consultant rather than by representing a particular constituency.

Traditionally, the OECD has expressly avoided the hallmarks of administrative law-transparency, responsiveness, and public accountability. Meetings are closed to the public. Though not voiced openly, in the view of many OECD country delegates, the closed-door meetings provide a welcome alternative forum to what is often viewed as the developing country-dominated and politicized United Nations system. Coupled with the consensus requirement for Recommendations and Decisions, the OECD has eliminated much of the acrimony and political grandstanding in more transparent IGOs such as the UN's

12. Http://www.oecd.org/document/18/0,2340,en_2649_201185_2068050_1_1_1_1,00.html.

13. Anne-Marie Slaughter, The Real New World Order, 76 ForEIGN AFF. 183, 196 (1997). 
General Assembly. (No doubt, dealing with like-minded countries on many issues is seen as a benefit by many delegates, as well.)

Until recently, the OECD's only formal relations with civil society have been in the labor area through its two nongovernmental partners-the Trade Union Advisory Committee (TUAC) ${ }^{14}$ and the Business Industry Advisory Committee (BIAC).$^{15}$ As the case study about the Multilateral Agreement on Investment (MAI) illustrates,${ }^{16}$ the institutional failure to formally consult other sectors of civil society fundamentally undermined the OECD's effectiveness in developing global rules for investment and eventually killed the process. Nor is there an accountability mechanism similar to the World Bank's Inspection Panel or the International Finance Corporation's Ombudsman that can review and assess the OECD's actions.

In some respects, this lack of administrative safeguards is not surprising. After all, the OECD was initially created to administer economic aid and to promote capitalism, not to promulgate standards or engage non-state actors. ${ }^{17}$ Over time, however, while the OECD's activities have evolved through setting standards, adopting guidelines, and hosting treaty negotiations, its organizational procedures have not kept pace. The result is an organization whose administrative safeguards are in flux-struggling over how much and what types of engagement with non-state actors are necessary without undermining the organization's basic mission.

III

\section{CASE STUdies}

This article is a positive rather than a normative endeavor. The chosen case studies illustrate the range of administrative law models developed by the OECD, as well as the development of these models over time. The objective of this case analysis is to examine why particular models were chosen and how effective they have been in furthering the goals of the OECD.

14. TUAC is the formal representative of labor organizations to the OECD. Originally created in 1948 to provide advice to the OEEC in its implementation of the Marshall Plan, TUAC has continued to provide feedback from the international labor community through regular consultations with OECD committees, the OECD secretariat, and Member country delegates. Based in Paris, TUAC is a freestanding organization with affiliates from over fifty-six national trade unions in the thirty OECD Member countries, representing approximately sixty-six million workers. http://www.tuac.org/about/ cabout.htm.

15. The Business and Industry Advisory Committee to the OECD (BIAC) was created at the time of the OECD's birth in 1962. An independent organization, BIAC is regarded by the OECD as its official link with employers-business and industry interests. In terms of interactions with the OECD, BIAC shares many of the same features as TUAC. It holds regular consultations with the OECD secretariat, committees and groups in order to provide an institutional counterbalance to the efforts of TUAC.

16. See infra Part III.

17. An interesting question is why the OECD's institutional outreach efforts to civil society only extended to labor and employer groups. This is merely speculation, but a possible explanation was the political importance of labor parties in OECD countries in the 1950s and the prominent, formal role unions and employer organizations played in domestic politics. 
The first case study presented, the failed attempt to negotiate a Multilateral Agreement on Investment (the MAI), shows clearly the price the OECD paid for not reaching out to civil society. It is an important case to start with because the OECD's public humiliation provided a powerful impetus for the organization to reconsider its administrative procedures. Institutionally, as a result of its bruising interactions with governments and civil society, the OECD's perception of itself and the public's perception of the OECD dramatically changed from an inward-focused niche organization to a major international player under bright scrutiny from civil society.

The second case study explores the Mutual Acceptance of Data system. Run by the OECD's Chemicals Division, this has been an extremely successful harmonization program that effectively sets laboratory and chemical safety test standards on behalf of national agencies. It provides a model of extensive engagement with stakeholders that is as transparent and responsive as any rulesetting process in the international arena.

The third case study explores development of the Common Approaches on Export Credits. Although negotiated after the MAI debacle, on its face the Common Approaches negotiations appear to have followed the same process. A closer look, however, suggests a clear understanding existed between the OECD secretariat and member states over the need for civil society engagement and, importantly, where and when it should take place. The last case looks at an interesting model for accountability-the OECD Guidelines for Multinational Enterprises. Although in existence since 1976, the Guidelines were extensively revised in 2000 and now offer a fascinating international quasijudicial process that operates in practice at the national level.

\section{A. The Multilateral Agreement on Investment (MAI)}

The past twenty years have witnessed unprecedented increases in foreign direct investment (FDI). Flows of foreign capital to developing countries dramatically increased in the $1990 \mathrm{~s},{ }^{18}$ with a forty percent increase in FDI inflows from 1994 to 1995 alone. ${ }^{19}$ Total FDI now exceeds the value of goods in international trade by more than five-fold, ${ }^{20}$ yet, remarkably, no comprehensive

18. Jean Raymond Homere, Intellectual Property Rights Can Help Stimulate the Economic Development of Least Developed Countries, 27 COLUM. J. L. \& ARTS 277 (2004). "In the early 1990s, Poland experienced a forty-fold increase in inward FDI following its rapid liberalization and deregulation program. .. China experienced a ten-fold increase in FDI between 1990-1995, receiving nearly $\$ 36$ billion in 1995. Additionally, Mexico experienced a sharp increase in FDI following the passage of NAFTA, as did Chile." Id.

19. Eric M. Burt, Note, Developing Countries and the Framework for Negotiations on Foreign Direct Investment in the World Trade Organization, 12 AM. U.J. INT'L L. \& POL'Y 1015, 1019 (1997).

20. Kenneth Vandevelde, Sustainable Liberalism and the International Investment Regime, 29 MiCH. J. INT’L L. 373, 382 (1998).

21. Id.; Sol Picciotto, Linkages in International Investment Regulation: The Antinomies of the Draft Multilateral Agreement on Investment, 19 U. PA. J. INT'L. ECON. L. 731, 744 (1998); Burt, supra note 19, at 1016. 
agreement exists at the international legal governing FDI. ${ }^{21}$ Absent coverage in the GATT or other economic treaties, the international legal framework governing FDI has developed in a piecemeal, incremental approach through a broad network of bilateral investment treaties (BITs). Mirroring the growth of FDI, the number of BITs has dramatically increased, as well. From 1989 to 1995, more BITs were negotiated to completion than during the previous three decades. $^{22}$ By 1995, over nine hundred BITs had been signed between more than one hundred and fifty nations. ${ }^{23}$ BITs both establish and clarify the rights of foreign investors. Most BITs share the same basic protections-national treatment, most favored nation (MFN) treatment, prohibition of exchange controls, prohibition of uncompensated expropriation, and resolution of disputes by binding arbitration. ${ }^{24}$ One important limitation of BITs is that they have not addressed linkages with other fields. ${ }^{25}$

If the only concerns raised by FDI were expropriation of property and repayment of debts, this lack of linkages would make good sense. But FDI, in practice, can have a direct relation to labor, environmental and other social welfare concerns because the goals of multinational enterprises (MNEs) and host countries may conflict. ${ }^{26}$

The fragmented nature of BITs encouraged a number of countries to seek to harmonize the patchwork of BITs through an MAI during the Uruguay Round negotiations leading to the creation of the World Trade Organization. The United States and others had proposed a comprehensive investment agreement but faced concerted opposition from developing countries. ${ }^{27}$ Against this backdrop of failure, in the early 1990s the OECD's Committee on International Investment and Multinational Enterprises (CIME) commenced a research project known as the Wider Investment Instrument Project. The OECD member countries sought to bring order to the proliferation of FDI and BITs through an agreement that consolidated the many BITs in an MAI. Following the completion of over seventy preparatory studies, in 1995, CIME and the Committee on Capital Movements and Invisible Transactions (CMIT) reported to the OECD Council that "the foundations have now been laid for the successful negotiation of ... [an MAI] building on OECD's existing instruments and expertise."28

22. Kenneth Vandevelde, Bilateral Investment Treaties, 90 A.J.I.L. 545 (1996) (book review).

23. $I d$.

24. Vandevelde, supra note 20 , at 373 n.2.

25. TUAC claimed that none of the 1600 BITs address labor issues. Interview by the author with TUAC personnel (December 1998).

26. Trying to increase employment, for example, countries have employed a range of operational restrictions (also known as performance requirements) such as mandating the hiring of local workers and limiting the ability of the company to employ foreign employees. For this reason as well as concerns over sovereignty, developing countries have preferred negotiating BITs and, with few exceptions, uniformly opposed strong multilateral rules liberalizing FDI under the auspices of the GATT or WTO.

27. The substantive reasons for this opposition are set out, infra note 34 .

28. OECD, A Multilateral Agreement on Investment: Report by the Committee on International Investment and Multinational Enterprises (CIME) and the Committee on Capital Movements and Invisible Transactions (CMIT), Paris, 1995. 
The stated goal was to complete the treaty by May 1997. A high-level negotiating group was established with the mandate to create an agreement that would

provide a broad multinational framework for international investment with high standards for the liberalisation of investment regimes and investment protection and with effective dispute settlement procedures; be a free-standing international treaty open to all OECD Members and the European Communities, and to accession by non-OECD Member countries. ${ }^{29}$

From the outset, the MAI negotiations were regarded internally by the secretariat as a technical harmonization exercise. Given that there was a great deal in common among the many investment treaties, it was expected that the OECD secretariat would review the range of BIT texts, identify common features, and create a unifying draft that would form the basis of a general agreement. The MAI, it was hoped, would be the first comprehensive international investment treaty creating uniform rules for FDI protection, liberalization, and dispute settlement. By creating a more level playing field than the bumpy terrain of BITs, the MAI would greatly reduce distortions to investment flows and therefore speed the growth of FDI, significantly promoting the liberalization of investment measures and performance requirements beyond the results of the Uruguay Round agreements.

The draft MAI as originally proposed was based upon the principles of national treatment, most-favored nation treatment, and transparency. It would have restrained governments from treating foreign and local investments differently than domestic investments, moving closer to a baseline of nondiscrimination. The agreement sought to harmonize upward by creating mechanisms addressing standstill and rollback of investment measures. ${ }^{30}$ Indeed, the MAI was less an attempt to regulate FDI than an effort to deregulate FDI flows. ${ }^{31}$

The MAI negotiations were announced in OECD press releases, articles were published in the organization's magazine, the OECD Observer, and many of the conference papers were posted on the OECD internet website created for the MAI in June 1996. The OECD even held an early press conference to discuss issues concerning negotiation of the MAI, but no one showed up. This confirmed CIME's view that negotiation of the MAI was purely a technical

29. David Robertson, The MAI Affair, A Story and its Lessons, 17, available at http://www.cairnsgroupfarmers.org/ni/reportspapers/maipaper.pdf.

30. Standstill measures prohibit the introduction of additional non-conforming measures. Rollback measures allow only future liberalization of measures.

31. It is beyond the scope of this study to examine the MAI's text in detail, but it is important to recognize that despite the reassurances of its proponents, the MAI did more than simply harmonize BITs. For a discussion of the specific reasons behind NGO opposition, see Salzman, supra note 1 , at 824 . 
harmonization exercise and there was no public interest in the matter. ${ }^{32}$ With the exception of NAFTA, which is more a trade than an investment treaty, none of the previous BITs had ever been met with outrage or even interest by NGOs.

Given this intense indifference to the MAI from the outset, why did an effective global coalition of labor, environmental, and other groups form explicitly against the MAI just two years later? From the end of 1995, a small number of NGOs started to follow the negotiations and oppose both the goals and content of the MAI process. At the start, these were primarily environmental and social, rather than labor, groups. The OECD held an informal meeting with interested NGOs in December of 1996. The OECD was open in terms of announcing the process of the negotiations and their general status but, in keeping with OECD procedures, the meetings and internal documents were restricted. In February 1997, the group Public Citizen, founded by Ralph Nader, obtained a copy of the current Chairman's draft (that is, the consolidated negotiating text up to that point) and posted it on the Internet. ${ }^{33}$ This posting provided the catalyst for widespread, hard line NGO opposition against the MAI. ${ }^{34}$

Many of those involved in the campaign described the NGO opposition as a wildfire. Indeed, the rapidity and effectiveness of NGO opposition to the MAI was unprecedented. Just two months after the initial posting, a more formal meeting for NGOs was hosted by members of the Negotiating Group and secretariat officials. The OECD's first consultative meeting with interested groups about the MAI had been in an empty room; the October briefing, by contrast, attracted representatives from forty groups around the world. ${ }^{35}$ In a mere matter of months, through the internet and e-mail, a global campaign against the MAI had come into being. Drafts and bulletins on the MAI were now regularly posted on a host of NGO websites. ${ }^{36}$ By 1998, anti-MAI campaigns were active in more than half of the OECD countries as well as many developing countries. $^{37}$

The global NGO campaign against the MAI rapidly achieved a powerful impact. By the time the Chairman's draft was issued in early 1998, many of

32. In a revealing anecdote on how low-profile the MAI exercise was within the OECD, a member of the OECD secretariat related that she was at a U.N. Commission for Sustainable Development meeting in 1996 when an NGO participant started denouncing the MAI negotiations. The European Union delegate had to call back to Paris to ask what the MAI negotiations were. Interviews with OECD personnel. December 12, 2003.

33. Stephen Kobrin, The MAI and the Clash of Globalizations, 112 FOREIGN POL'Y 97, 97-98 (Fall 1998).

34. NGOs criticized the legitimacy of the closed door process, but their fundamental concerns were substantive. They charged that the MAI weakened the regulatory capacity of host countries in favor of investor protections. Under the guise of technical harmonization, in other words, the MAI negotiations were imposing an undesirable policy choice with the potential to fundamentally change the status quo.

35. Robertson, supra note 29 , at 41.

36. See, e.g., http://www.citizen.org/trade/issues.

37. Robertson, supra note 29 , at 46. 
TUAC's initial demands had been met. Despite earlier protestations by some member countries, text was inserted to prohibit the lowering of social and environmental standards to attract FDI, to ensure that treaty obligations would not prevent governments from maintaining (or heightening) protective social and environmental standards, and to ban claims by foreign investors for compensation for losses caused by non-discriminatory regulatory actions. These concessions, however, came too late, for the NGO campaign had taken on a life of its own in domestic politics. In early 1998, seeking to resurrect the chances of renewed Fast Track trade authority from Congress, the Clinton Administration sought NGO support by denouncing the MAI as "fatally flawed" and demanding it be reconsidered. Domestic opposition also flared up in Paris, where demonstrations in February took aim at the impact of the MAI on France's ability to protect its cultural heritage. In response, the MAI negotiations were formally suspended for a six-month period of assessment by the negotiating parties. On October 14, France, one of the MAI's strongest early proponents, announced it would pull out of the negotiations. France's abandonment of the negotiations meant the E.U. had to follow, effectively dooming the OECD's negotiation of an MAI. Reflecting this course of events, the OECD issued a press release on December 3 stating that "Negotiations on the MAI are no longer taking place." 38

The MAI proved to be a watershed experience for the OECD. For the very first time, the OECD was the target of a high-profile NGO campaign. Flatfooted and caught by surprise, the OECD's response to public criticism had been ineffective and, sensing the domestic political winds, governments publicly criticized the OECD activities for the first time, as well. Such scrutiny was both unexpected and unwelcome. Following the MAI, the challenge to the OECD was clear-it needed to reassess its relationships with NGOs beyond TUAC and BIAC in order to prevent future high-profile casualties. This task would be made easier, though, by the fact that some of the other OECD directorates already had longstanding and successful mechanisms in place for engagement with non-state actors. This process is further explored in Section B.

\section{B. Mutual Acceptance of Data}

One of the most influential OECD programs on domestic agency action has also been among the least known. Since the 1980s, the Chemicals Division of the Environment Directorate has administered a mutual recognition system for the non-clinical safety data of chemicals. Known as the Mutual Acceptance of Data (MAD) system, member countries and non-member countries agree to accept non-clinical safety data from one another. These data are relied on by governments to evaluate the safety of a staggering range of products, such as chemicals, pesticides, pharmaceuticals, cosmetics, food, feed additives and biocides.

38. Id. at 17 . 
In simple terms, the MAD system ensures that chemical test results produced in one country will be accepted when an agency assesses the same chemical in another country. Thus, in practice, governments that receive requests to approve the sale of industrial chemicals, pharmaceuticals, or pesticides can base their decisions on testing results from other countries. This saves the chemicals industry the expense of repeatedly testing products for sale in different markets and promotes civil society concerns over data quality and transparency of test methodologies and lab standards. ${ }^{39}$ In an era of falling tariffs, non-tariff barriers to trade have become increasingly important. The MAD system reduces the threat of non-tariff barriers by harmonizing safety tests and lab standards across the range of commercial chemicals.

It is important to note that the MAD system addresses the safety testing of the chemicals, not the decision whether the chemicals are safe enough be sold on the market of any particular country. In technical terms, the MAD system provides common risk assessment data while risk management is left to each member country. The system is founded on three legally binding Council Decisions. ${ }^{40}$ Thus, except for a narrow exception described below, member countries must accept test results from other participating countries. ${ }^{41}$

All thirty OECD members participate in the MAD system-twenty-five have implemented the 1981 and 1989 Council Acts through national legislation and regulation, two are establishing monitoring programs, and the remaining three have not implemented the Council Decisions, but must accept data from other participating countries. The system is clearly effective, for there has been growing interest from non-member countries. South Africa became a full participant in 2003; Slovenia, Israel and India are joining soon; and negotiations are underway with Brazil, China and the Russian Federation.

For such a system to work, of course, the participating governments must be confident that the tests on the chemicals were both relevant and properly administered. This is ensured through the OECD Test Guidelines and Principles of Good Laboratory Practice (GLP). Thus, all test data submitted to agencies

39. A study for the OECD found yearly net savings from MAD to be $\$ 54$ million ( $\$ 63.5$ million savings from avoided testing, less $\$ 9.5$ million in program administration. Rob Visser, OECD Chemicals Division, Personal Communication to James Salzman, Dec. 12, 2003.

40. The three decisions are:

- Decision of the Council Concerning the Mutual Acceptance of Data (MAD) in the Assessment of Chemicals, OECD Doc. C(81)30 (May 12, 1981), with its associated Test Guidelines and Principles of Good Laboratory Practice (GLP);

- Council Decision-Recommendation on Compliance with Good Laboratory Practice, OECD Doc. C(89)87, (Oct. 2, 1989);

- Council Decision on the Adherence of Non-Member Countries to the Council Acts related to the Mutual Acceptance of Data in the Assessment of Chemicals, OECD Doc. C(97)114, (Nov. 26, 1997).

41. The relevant Decision text states that "data generated in the testing of chemicals in an OECD Member country in accordance with OECD Test Guidelines and OECD Principles of Good Laboratory Practice shall be accepted in other Member countries for purposes of assessment and other uses relating to the protection of man and the environment." Decision of the Council Concerning the Mutual Acceptance of Data (MAD) in the Assessment of Chemicals, Part 1(1) at 2. 
must include a declaration by the test facility that the appropriate Test Guideline was followed and that the testing was carried out in accordance with GLP Principles.

Approximately one hundred Test Guidelines have been developed. ${ }^{42}$ As their name suggests, they are basically recipes for how particular types of tests should be done. If one is testing the toxicity of a chemical on aquatic organisms, for example, the relevant Test Guidelines will state the type of organism to use (for example, daphnia), how the doses should be administered, and how toxicity should be measured.

The GLP Principles focus not on the tests themselves but on the conditions under which the tests are carried out. Established in 1978, three years before adoption of the MAD system, the GLP Principles seek to ensure the quality and validity of test data. The Principles focus on the organizational processes and conditions under which laboratory studies are planned, performed, monitored, recorded and reported. As an example, the GLP Principles for storage require, among other procedures, that

To prevent contamination or mix-ups, there should be separate rooms or areas for receipt and storage of the test and reference items, and mixing of the test items with a vehicle. Storage rooms or areas for the test items should be separate from rooms or areas containing the test systems. They should be adequate to preserve identity, concentration, purity, and stability, and ensure safe storage for hazardous substances. ${ }^{43}$

OECD working groups meet regularly to manage the MAD system. These groups oversee publication of Consensus Documents on interpretation of the Principles, Guidance Documents, and Advisory Documents, all of which promote development of new standards and revision of existing ones. In a practice that stands in stark contrast to how the rest of the OECD has traditionally operated, the working groups actively engage industry and civil society to reach consensus on Testing Guidelines and GLP Principles. This occurs both through participation of non-state experts at meetings and, more important, through a network of seven thousand experts for peer review and validation of proposed new Test Guidelines and updates. This network has a broad membership, with participants from industry, trade unions, academia, and environmental and animal welfare NGOs.

The participation of civil society NGOs not only adds scientific expertise, but also helps ensure that the process remains transparent. BIAC and TUAC have full participation rights in the meetings, while other non-state actors participate as observers. To increase their voice, environmental groups are generally represented by a single member of the European Environment Bureau who speaks with authority on their behalf. Seeking to achieve the same unified voice, in a clever strategy, animal welfare groups have formed a group known as

42. These are in the areas of physical-chemical properties, human toxicity, ecotoxicity, and degradation and accumulation.

43. OECD Series on Principles of Good Laboratory Practice and Compliance Monitoring No. 1, OECD Doc. ENV/MC/CHEM(98)17, § 3.3 at 21 (1997). 
the International Council for Animal Protection in OECD Programmes (ICAPO) ${ }^{44}$ ICAPO was created explicitly to participate in the GLP and Test Guideline working groups with an equal voice to the EEB. Of course, the interests of the NGOs these groups represent are not identical. Environmental and consumer NGOs, for example, often want to increase the number of animals required per test to understand better the effects on the environment and human health, while animal welfare NGOs want to reduce those numbers.

How does this process work in practice? Hazard data of chemicals is routinely needed on skin irritation, acute toxicity, and other basic effects. A proposal for a test method can come from anyone, but it usually comes from an agency or industry that wants to update a test method or have a new one adopted. A group of government and non-state experts considers the request and, if deemed worth pursuing, the proposed test is sent out for comments (as well as posted on the website). If, after revisions based on the peer review comments, the test method is close to adoption, the proposal is sent to national coordinators at relevant domestic agencies. They make the decision whether to approve or continue development. If approved, the test method is sent to the Environment Directorate's governing committee for approval, and then on to the OECD Council. Once adopted by members, the test method has legally binding force as a Council Decision.

The controversy over genetically modified organisms (GMOs) shows just how well this system works. While the U.S. and Europe have recently moved their battle over GMOs to the WTO dispute settlement process, several years ago, with tempers still flaring across the Atlantic, the OECD was able to reach consensus among its members on how GMOs should be tested for safety. The MAD system has been able to navigate the controversial animal welfare debate as well, developing testing methodologies using cultivated cells or tissues (the so-called in vitro or in silico tests). The OECD has been able to make progress on such divisive issues by focusing only on the harmonization of data requirements for use in member countries' regulatory processes.

Although OECD member countries agree on many issues, there are occasional fundamental disagreements. The MAD system has successfully dealt with such disagreements by partitioning the technical aspects from the political. Thus, the contentious political decisions over whether to approve a chemical or product lie in the hands of regulatory agencies and are explicitly not part of the MAD system.

Similar to the MAD system, the GLP system ensures harmonized standards for how laboratories carrying out the tests should be managed. As part of the 1981 OECD Decision, member governments are required to

44. ICAPO defines its mission as seeking "to promote new test guidelines [that] fully incorporate alternative methods that can replace, reduce, and refine animal use (the 'Three Rs'). Similarly, ICAPO will seek to limit animal use and promote alternative methods in OECD testing programs, such as the OECD's emerging programs to assess 'high production volume' chemicals and 'endocrine disrupting' chemicals." http://www.hsus.org/ace/16124. 
i) establish national procedures for monitoring compliance with GLP Principles, based on laboratory inspections and study audits;

ii) designate an authority or authorities to discharge the functions required by the procedures for monitoring compliance; and

iii) require that the management of test facilities issue a declaration, where applicable, that a study was carried out in accordance with GLP Principles and pursuant to any other provisions established by national legislation or administrative procedures dealing with good laboratory practice. $^{45}$

Each government is required to set up its own GLP compliance monitoring procedure and ensure its domestic regulatory practices are consistent with the OECD decision, but there is no uniform model for doing so. For European Union countries, this is done directly through community legislation. All OECD Test Guidelines and the GLP principles are transcribed directly into European Directives without amendment. In all, twenty-five OECD countries have implemented the 1981 and 1989 Council Acts through national legislation and regulation. ${ }^{46}$

The United States has not adopted the GLP Principles and Testing Guidelines directly. Although the OECD standards inform the U.S. Food and Drug Administration's actions, the FDA promulgates its own GLP and Testing Guidelines as informal rules, often going beyond what is required by the GLP. ${ }^{47}$ The EPA has its own FIFRA and TSCA GLP Principles, for example, which are comparable to the OECD's. ${ }^{48}$

Member states are required to appoint authorities and establish procedures to monitor compliance with GLP Principles, including laboratory inspections and study audits. Member states are also expected to exchange information with one another and to provide information about compliance of their national GLP test facilities to other member states. Despite these requirements, in a small number of cases countries have refused to accept safety data for product evaluation, contending that they had concerns over the effectiveness of GLP compliance monitoring procedures in the country where the data had been generated. This has been a particularly controversial issue for the United States. While the FDA generally accepts test data, in the mid-1990s it challenged E.U.

45. Decision of the Counsel concerning the Mutual Acceptance of Data (MAD) in the Assessment of Chemicals, OECD Doc. C(81)30(Final), Annex 2, (May 12,1981), available at http://www.oecd.org/ dataoecd/39/15/2017640.pdf.

46. Two OECD countries are currently establishing monitoring programs, and three have not yet implemented the Council Decisions, though they are required to accept data from the other participating countries.

47. Japan, too, sometimes requires additional testing (for example, a 28-day test with an added control beyond what is called for in the Test Method). This is appropriate since the Council Decision establishes a floor, not a ceiling. One can ask for additional tests, in other words, but not different tests.

48. Rob Visser, OECD Chemicals Division, Personal Communication to James Salzman, Dec. 12, 2003 (on file with author). 
testing on a number of occasions, demanding assurances that the declarations of compliance with the Test and GLP Guidelines were accurate. ${ }^{49}$

Concerns over how adequately countries were monitoring compliance with GLP Principles and Test Guidelines came to a head in the late 1990s, when the Working Group on GLP established an informal system of evaluation. Known as "mutual joint visits," over a three-year period all thirty-four GLP compliance monitoring authorities were visited by three-person teams drawn from three other national authorities. The visiting teams evaluated the program documentation and accompanied staff on inspections and study audits. The visit reports were reviewed in the Working Group, which then made recommendations on necessary improvements. The reviews were informal, yet peer pressure was significant and apparently has been sufficient to bring about specific changes in program management. When evaluated by the OECD Chemicals Committee in 2002 , it was agreed that the same procedures should be continued and extended to non-OECD countries in the system. Two additional requirements are worth noting in this regard, as well. Not only must authorities now circulate annual overviews of all inspections among themselves and study audits they carry out, but, when it has good reason for doing so, another member country can request information concerning GLP compliance of a test facility (including information focusing on a particular study). ${ }^{50}$

The MAD system is truly unique among IGOs in both substance and procedure. In substantive terms, no ISO standards (or any other standards, for that matter) can compare in terms of regulatory acceptability to the GLP Principles and Test Guidelines. In procedural terms, the system is unlike any other administrative processes at the OECD. International, mandatory standards are set, placing the OECD in the effective role of a regulator. All meetings are open to non-state actors (except when GLP inspections are discussed). All documents are unrestricted and free. Decisions rely on the contributions of a large network of non-state experts. The process is supported both by industry and civil society groups. Compliance with standards is assured by regular site visits and the effective use of peer pressure. And the system is open to nonOECD countries (indeed, non-member participation is encouraged).

The broad-based, inclusive MAD program stands in stark contrast to the secretive and closed MAI process of engagement with civil society. It also is widely regarded as a success. Given the MAI debacle and the MAD experience, after 1997 the interesting question became whether the MAD approach would guide other OECD directorates in their engagement with non-state actors. As the next section describes, the influence of both MAD and the MAI were significant but indirect.

49. It is worth noting that such an objection could not have been mandated in the United States through administrative law channels.

50. The group overseeing the mutual joint visits is the only Chemicals group restricted to government officials. This helps ensure frank and open discussion of compliance monitoring and enforcement weaknesses. 


\section{Common Approaches on Environment and Officially Supported Export Credits}

Export credit agencies (ECAs) are national agencies that offer loans, insurance, and guarantees to support domestic companies' overseas activities. ECAs represent one of the largest sources of public finance, with over $\$ 500$ billion of financing committed in 2001..$^{51}$ They are major development players, as well, accounting by the late 1990 s for over " 24 percent of all developing countries' debt, and 56 percent of the debt owed to official governmental agencies." 52

While financing overseas investment has helped spur development in poor countries, it has also led to significant controversy, particularly when the monies support large infrastructure projects with major environmental impacts. A high-profile project in Batu Hijau, Indonesia, for example, illustrates a typical conflict. A consortium of companies, involving the United States, Japan, and Indonesia, operate an open pit copper and gold mine. ${ }^{53}$ Upon completion, the mine will have excavated three billion tons of rock, creating a pit 2,625 meters wide and 460 meters deep. ${ }^{54}$ NGOs charge that the mine is located in a "previously undisturbed tropical forest," destroying local vegetation and the endangered yellow-crested cockatoo's habitat, affecting local water levels and quality, creating excess waste rock, and polluting the air. ${ }^{55}$ Another ECA-financed project, the Chad-Cameroon Petroleum Pipeline, has proven equally controversial. The pipeline transports oil from Doba, in southern Chad, to an off-shore oilloading facility on Cameroon's coast. ${ }^{56}$ Financed by the World Bank Group and the International Finance Corporation, as well as by Exxon-Mobil, Petronas, and Chevron-Texaco, the project has allegedly caused serious harm to Cameroon's Atlantic littoral rainforest and the indigenous Bakola pygmies who live in the region. ${ }^{57}$ One could list many other ECA-supported projects in the mining, pulp extraction, oil, and power development sectors that face similar criticism. Traditionally, however, ECAs have not considered the environmental impacts

51. According to the World Bank, ECAs' "total exposure to developing countries reached an estimated $\$ 500$ billion at the end of 2000-one-quarter of developing countries' long term debt." The World Bank, Global Development Finance: Financing the Poorest Countries, 2 vols. (Washington, DC: Office of the Publisher, 2002), I: 107 in Globalization's Most Perverse Secret (paper presented May 2324, 2002), available at http:/www.environmentaldefense.org/documents/2487_Globalizations_ Secret.pdf, at 5; see also http://www.halifaxinitiative.org/updir/dynamicPDFcache/BE-Section-Issues_ ECA_FAQ-1110637439.pdf, at 2.

52. Jakarta Declaration for Reform of Official Export Credit and Investment Insurance Agencies (May 1-7, 2000), available at http://www.eca-watch.org/goals/jakartadec.html (last visited Apr. 18, 2005).

53. U.S. Gen. Accounting Office, Rep. No. GAO-03-1093, Export Credit Agencies, Movement Toward Common Environmental Guidelines, but National Differences Remain, $35-36$ (Sept. 2003), available at www.gao.gov/new.items/d031093.pdf (last visited Apr. 18, 2005).

54. Id.

55. See id. at 36. (stating that in 1997 the Export-Import Bank began requiring a series of environmental reviews, and that project developers seek to alleviate the environmental effects with a deep-sea tailings disposal system, operating a revegetation program, and initiating a study of water seepage patterns).

56. Id. at 38-39.

57. Id. at 39. 
of projects, leaving it to host governments to establish appropriate regulations and ensure enforcement. ${ }^{58}$

Seeking to change this practice, a concerted NGO campaign in the 1980s focused on World Bank activities. This contributed to the World Bank's adoption of a series of internal policies and procedures to guide the Bank's assessment and implementation of projects with environmental impacts. In 1984, for example, the Bank adopted Operational Manual Statement 2.36 on Environmental Aspects of Bank Work, setting forth eight principles to guide Bank activities. The principles include commitments not to finance projects that "cause severe or irreversible environmental deterioration, including species extinction without mitigatory measures acceptable to the Bank" or to "finance projects that contravene any international environmental agreement to which the member country concerned is a party." 59 These were followed by specific Operational Directives, Bank Procedures, and Good Practices that set out environmental steps and policies Bank staff must follow in all Bank operations and projects. $^{60}$

In 1995, a year after the World Bank's adoption of an environmental policy, the United States Export-Import (Ex-Im) Bank became the first national ECA to develop minimum environmental standards and evaluation procedures, entitled "Environmental Procedure and Guidelines." 61 The Ex-Im Bank developed two types of guidelines: quantitative or numerical guidelines to assess air emissions, water quality, and noise impacts; and qualitative guidelines to assess the project's ecological, economic, and cultural impacts. ${ }^{62}$ In practice, all applicants to the Export-Import Bank for long term transactions, including those projects with a principal liability of more than $\$ 10,000,000$ or a repayment term of more than seven years, are required to prepare an "Environmental Screening Document." ${ }^{63}$ If the project poses potentially adverse environmental impacts, an environmental assessment may be required. ${ }^{64}$ Most transactions, though, do not

58. In the United States, for example, Ex-Im Bank funding decisions are not subject to review under Executive Order 12114, requiring environmental impact reviews of actions with foreign impacts.

59. David Hunter, The World Bank: A Lighter Shade of Green?, in YEARBOOK OF INTERNATIONAL CO-OPERATION ON ENVIRONMENT AND DEVELOPMENT 2001/2002, 61 (Olav Schram Stokke \& Øystein B. Thommessen eds., 2001), available at http:/www.greenyearbook.org/ articles/01_06_hunter.pdf.

60. See generally, DAVID Hunter, JAmES SAlZMAn \& DURWOOd ZAELKe, InTERNATIONAL ENVIRONMENTAL LAW AND POLICY 1482 (2d ed. 2002).

61. Environmental Review Procedures, Export-Import Bank of the U.S., 61 Fed. Reg. 17,701-01 (Apr. 22. 1996). For further detailes, see http://www.exim.gov/products/policies/environment/ envproc.html.

62. See Export-Import Bank of the United States, International Environmental Guidelines, Annex A, (May 1998, revised July 2, 2003) at http://www.exim.gov/products/policies/environment/ envguide.html (last visited Apr. 18, 2005).

63. Export-Import Bank of the United States, Ex-Im Bank Environmental Procedures and Guidelines (revised July 7, 2004), at http:/www.exim.gov/products/policies/environment/envproc.html (last visited Apr. 18, 2005).

64. See id. (stating what the environmental assessment should include). See also Export-Import Bank of the United States, Environmental Procedures, Introduction (revised July 2, 2003) (listing the categories as Category N: Nuclear, Category A: Large Greenfield Projects or Projects located in, or im- 
require a review, either because they are short-term transactions or are not environmentally sensitive. ${ }^{65}$

Landing contracts for large foreign projects is a highly competitive business, and the support provided by ECAs can make or break a deal. With mandatory environmental guidelines in place, the Ex-Im Bank found itself at a competitive disadvantage to national ECAs that did not have to meet similarly stringent standards. Thus, the United States started lobbying for OECD members to adopt similar standards. (The United States followed a similar route in pushing for a Bribery Convention at the OECD that mirrored the requirements of the Foreign Corrupt Practices Act.) In 1997, for example, at the Denver G-7 Summit, the Final Communique for the Summit stated that "[g]overnments should help promote sustainable practices by taking environmental factors into account when providing financing support for investment in infrastructure and equipment." ${ }^{66}$

The efforts of the United States to harmonize strict standards were supported by a global NGO campaign, spearheaded by ECA Watch and the International NGO Campaign on Export Credit Agencies. These groups called for "public access to information and consultation by ECAs ... [and for] [b]inding common environmental and social guidelines and standards that are not lower and less rigorous than existing international procedures." ${ }^{\prime} 7$

In 1998, the OECD responded, and the Trade Committee's Working Party on Export Credits and Credit Guarantees (ECG) issued a "Statement of Intent on Export Credits and the Environment" discussing the consideration of environmental impacts during the risk assessment stage of various projects. A year later, the G-7 and OECD Ministers expressly called for development of common international standards and commenced negotiations at the OECD, and the OECD soon after adopted an "Action Statement," outlining a framework of "Common Approaches" for ECA activities. ${ }^{68}$

pacting a Sensitive Site [requires submission of an environmental assessment and related documentation describing the environmental effects of the project], Category B: Expansions, Upgrades and Projects Having Limited Environmental Impact [requires submission of environmental information sufficient to establish whether or not the project meets relevant host-country environmental guidelines and applicable international guidelines], Category C: Categorical Exclusions [no further environmental information is required because the project has minimal environmental impact], at http://www.exim.gov/products/policies/environment/envproc.html (categories revised July 1, 2004 to be consistent with OECD Common Approaches.)

65. U.S. Gen. Accounting Office, supra note 53 at 4.

66. Nicholas Hildyard, Snouts in the Trough: Export Credit Agencies, Corporate Welfare and Policy Incoherence, ECA Watch, at http://www.eca-watch.org/eca/snouts4.html (last visited Feb. 20, 2005).

67. Campaign Goals, ECA Watch, at http://www.eca-watch.org/goals/index.html (last visited Jan. 24, 2004). The clearest statement of the NGOs' position was the Jakarta Declaration for Reform of Official Export Credit and Investment Insurance Agencies issued in May, 2000. See supra, note 52. Based on the experiences of Indonesia and other developing country hosts of ECA-backed projects, the Jakarta Declaration called for the development of "binding common environmental and social guidelines and standards no lower and/or less rigorous than existing international procedures and standards ... coherent with . . . the United Nations Convention on Biological Diversity." Id.

68. The Action Statement declared: 
Following intensive negotiations, the ECG produced a draft "Recommendation on Common Approaches on Environment and Officially Supported Export Credits." Known as "The Sixth Revision of the draft Common Approaches," it called on ECAs to screen and classify projects in sensitive areas for potential environmental impacts, conduct an environmental review (and, where needed, a more comprehensive Environmental Impact Assessment), evaluate and disclose the information from the review, and, finally, report and monitor their experiences at the national level. ${ }^{69}$ When it came time for adoption, both Turkey and the United States objected to the draft. Turkey based its objection on concerns over language that might address their treatment of the Kurds; the United States held out for a stronger text that more closely resembled its domestic laws. Lacking consensus approval, the Common Approaches were not adopted as a Recommendation.

Despite this failure, OECD Secretary-General Donald J. Johnston lauded the Common Approaches as "an important first step," stating that "the implementation of this proposal by most members from January 2002 will mean that all major exporting countries of the OECD will now be applying environmental review mechanisms. This results in the first common 'greening' of export credits and should be seen as a major accomplishment." ${ }^{70}$ Surprisingly, even without official adoption by the OECD Council, the standards were voluntarily and uni-

(1) [Members agree to] continue to develop, within their national systems of official export credit support, procedures and methodologies for identifying and assessing the environmental impact of projects ....

(2) [Members agree to] continue to monitor and evaluate, over time, their own experiences with these procedures and methodologies, as well as their own experiences related to mitigating the environmental impact of individual projects, and share these experiences with the other Members ....

(3) [Members agree] based on ECAs' experiences (e.g. with Environmental Information Exchanges), to explore ways to synthesize common elements and best practices related to environmental review and impact assessment in order to strengthen a framework of common approaches amongst export credit agencies ....

(4) [Members agree to] exchange views on an informal basis with appropriate stakeholders.

Export Credits and the Environment: Work-Plan, OECD (Apr. 2000), at http://www.oecd.org/ document/7/0,2340,en_2649_34181_1888199_1_1_1_1,00.html.

69. In summarizing its goals, the Sixth Revision stated that it would

[p]romote coherence between policies regarding officially supported export credits and policies for the protection of the environment, including relevant international agreements and conventions, thereby contributing towards sustainable development[;] [d]evelop common procedures and processes relating to the environmental review of projects benefiting from officially supported export credits, with a view to achieving equivalence among the measures taken by the Members and to reducing the potential for trade distortion[;] [and p]romote good environmental practice and consistent processes for projects benefiting from officially supported export credits, with a view to achieving a high level of environmental protection.

Draft Recommendation on Common Approaches on Environment and Officially Supported Export Credits: Revision 6, Working Party on Export Credits and Credit Guarantees, OECD Doc. TD/ECG(2000)11/REV6 (December 14, 2001) available at http://www.oecd.org/dataoecd/2/32/ 2726700.pdf.

70. Statement by the OECD Secretary-General Donald J. Johnson on Export Credits and the Environment (Apr. 12, 2001), at http://www.oecd.org/document/33/0,2340,en_2649_34181_2675489_ 1_1_1_1,00.html. 
laterally incorporated throughout the OECD (including the United States and Turkey). Most members adopted the OECD standards as internal agency procedures or rules. From interviews with OECD staff, this appears to be the first time that a practice has been adopted throughout the OECD prior to Council adoption. This seems to have occurred due to the combination of strong external NGO pressure, the considerable resources expended to develop the Sixth Revision, and the near consensus that had been achieved during negotiations.

Responding to continued NGO and U.S. pressure, the ECG kept negotiating and finally adopted a revised Recommendation that was fully adopted in December 2003, including Turkey and the United States. Similar to the ExportImport Bank's policy, the Recommendation separates projects into categories requiring different levels of environmental review. ${ }^{71}$ This policy sets minimum international environmental standards that vary depending on the extent of impact. $^{72}$ With the most sensitive projects, the OECD advises that an Environmental Impact Statement be prepared and remain available for thirty calendar days before final commitment. The OECD Common Approaches also require transparency during the review process and public notice for consultation with affected groups. Despite a proposal from Japan for an accountability mechanism (and models in the World Bank Inspection Panel and the MNE Guidelines' National Contact Points), the ECG chose not to include a review mechanism or sanction process. In their place, members submit annual progress reports to the Working Group. ECAs must provide notification details of reviews of sensitive projects, and it is hoped that peer pressure will be enough to ensure compliance.

The Common Approaches seem to have been adopted domestically as an internal agency policy or procedure rather than through statute. The United States signed the 2003 Recommendation and may need to make some small modifications to the Export-Import Bank's guidelines (which already are renewed on a regular schedule). Since the Common Approach creates a floor rather than a ceiling and leaves flexibility for national adoption, there has been a wide range of implementation, with Austria and Germany essentially adopting the Common Approach (that is, no complaint or accountability mechanism) and the United Kingdom, theUnited States, Canada, and Japan going beyond the minimal standards.

71. See Recommendation on Common Approaches on Environment and Officially Supported Export Credits, OECD Doc., II, para. 4-6 (2003) (including in Category A any project that has the potential to create significantly adverse environmental impacts and including all projects in "sensitive areas" [as listed by Annex I], in Category B any project where the potential environmental impacts are less adverse than those of Category A and where mitigation is available and the effects are reversible, and in Category $\mathrm{C}$ any project that has minimal to no likely environmental impact), at http://www.oecd.org/dataoecd/26/33/21684464.pdf.

72. For instance, a Category A project requires an Environmental Impact Assessment that includes an "executive summary; policy, legal and administrative framework; project description; baseline data (involving the existing environmental conditions); environmental impacts; analysis of alternatives; environmental management plan; and record of consultation." This is based on the World Bank's Operational Manual. Id. at Annex II. 
The transparency and responsiveness of the process offers a fascinating insight into how things have changed at the OECD since the MAI experience. Negotiations over the Common Approaches followed directly on the heels of the MAI debacle but, at first glance, seemed to take little heed of the experience. If anything, the process seemed more closed than the MAI negotiations. Only representatives of ECAs sat at the table, and all documents were restricted. The only formal engagement with non-state actors was through periodic information meetings. Indeed, the only way the OECD environment secretariat was able to influence the proceedings was by sending draft restricted papers to Environmental Policy Committee delegates, who then sent them on to their national environmental agencies to influence development of domestic negotiating positions. In the negotiations following the Sixth Revision in 2001, a number of member states opposed sharing any documents with NGOs and, interestingly, no country delegation included NGO representatives.

Thus far, the process seemed identical to the MAI (and the way prior negotiations had occurred), yet NGOs exerted considerable influence on the Common Approaches process. How did this happen? Part of the answer lies in outside pressure. Groups such as ECA Watch were created explicitly to influence the Common Approach negotiations. Unlike the MAI experience, NGOs were aware from the outset of what was happening and created institutional mechanisms to stay engaged and to push for stringent standards. Interviews with the OECD secretariat staff indicate they were well aware of this outside scrutiny. ${ }^{73}$ Early on, the secretariat made it clear to member states that it was not the OECD's job to perform civil society consultations. The OECD effectively told NGOs that they needed to work to influence the process at their national capitals, and told member states that engagement with civil society would not be occurring at the OECD. Importantly, member states and NGOs responded. Many countries held formal stakeholder consultations several months prior to OECD negotiations in the fall of 2003. Japan had three weeks of open meetings with NGOs and the business community. France had a full day consultation, and the E.U., Germany, and Switzerland held meetings over the summer, as well. In addition, during negotiations countries would be saying, "This is unsellable at home to the government and NGOs." 74 Such statements, the OECD secretariat staff suggested, never would have been made prior to the MAI experience. When an information meeting was held just prior to formal negotiations in November, NGO and business groups made very specific comments that clearly were based on the (supposedly restricted) Chairman's draft. One can only conclude they were provided the draft by the member states.

The story of NGO influence and criticism of the Common Approaches is not over. ECA Watch argues that the Recommendation "perpetuates the ECAs' race to the bottom" by not requiring "ECAs to apply any specific mini-

73. Interview with OECD personnel secretariat in Paris, France (July 2003).

74. Interview with OECD secretariat in Paris, France (July 2003). 
mum set of [international standards] to projects, [and] deferring rather to a broad list of varying standards which they can elect to apply, or not, at will." 75 ECA Watch has not been entirely negative, however, describing the Recommendation as both an "opportunity and a threat ... [because] for a number of European ECAs, it will mean becoming much more transparent and finally joining the modern world of international norms, while others may use it as an excuse to move back into the stone age." Thus, interestingly, while ECA Watch and its member organizations continue to monitor the negotiations leading to revision of the Common Approaches and criticize the substance of the Recommendation, they have not criticized the administrative process of negotiating the Common Approaches. ${ }^{76}$

\section{OECD Guidelines for Multinational Enterprises}

Following revelations in the early 1970s of wide-scale unethical and illegal activities by multinational enterprises (MNEs), the U.N., ILO, OECD and national governments focused on means to influence their behavior. ${ }^{77}$ The U.N. General Assembly adopted a consensus resolution on measures against corrupt transnational practices, but failed to follow up with a stronger legal instrument. One year later, in 1976, the OECD Council of Ministers adopted a recommendation entitled the Declaration on International Investment and Multinational Enterprises. ${ }^{78}$

As its name suggests, the overriding purpose of the Declaration was to promote transnational investment. In its introduction and seven chapters, the Declaration and its accompanying Guidelines covered a wide breadth of issues governing investments. The separate chapters ranged from topics such as information disclosure, competition, and financing, to taxation, science and technology, but the requirements were voluntary, vague and hortatory. The Guidelines were necessary to promote investment, it was argued, in order "to prevent misunderstandings and build an atmosphere of confidence and predictability between business, labour and governments." ${ }^{79}$ The Guidelines, it was

75. Press Release, ECA Watch, Groups blast weak OECD agreement on environment: Loopholes allow export credit support for harmful projects to continue (Dec. 11, 2003), at http://www.ecawatch.org/press/PressReleaseOECDDecember11.htm (last visited Apr. 18, 2005).

76. Id.; see, e.g., ECA Watch, What's New! Vol. 4, No. 2 at $\S 13$ (Feb. 2005), at http://www.ecawatch.org/WhatsNew/WNV4_2005/WhatsNewV4N2.html (demonstrating that ECA Watch continues to follow developments at the OECD).

77. The best known examples during this period were the involvement of ITT and other U.S. companies in the 1973 Chilean coup that overthrew president Allende and the series of bribes paid by Lockheed to Japanese politicians for military contracts.

78. Declaration on Int'l Investment and Multinational Enterprises, in Declarations and Decisions on International Investment and Multinational Enterprises: Basic Texts, OECD Doc. DAFFE/IME(2000)20, 5-6 (June 21, 1976), revised June 27, 2000, at http://www.olis.oecd.org/olis/ 2000doc.nsf/4f7adc214b9a685c12569fa005d0ee7/c125692700623b74c1256991003b5147/SFILE/00085743. pdf (last visited Apr. 18, 2005).

79. http://www.oecd.org/documentprint/0,2744,en_2649_34889_2349370_1_1_1_1,00.html. 
hoped, would ensure the operation of MNEs was compatible with the expectations of the host country by establishing a baseline of rights.

The chapter on competition, for example, encourages MNEs to refrain from entering into or carrying out anti-competitive agreements among competitors, to fix prices, make rigged bids, establish output restrictions or quotas, or share or divide markets." 80 The chapter on employment and industrial relations was equally regarded with great hope when it was included in the final Declaration. Supported by both TUAC and BIAC_-both sides of the bargaining table_-it set forth labor rights of union representation, collective bargaining, meaningful engagement with management, and non-discrimination. ${ }^{81}$

Until revisions in 2000, implementation of the Guidelines commenced at the National Contact Points within national governments. National Contact Points (NCPs) serve as the initial stage of consideration for issues and conflicts arising under the Guidelines. Any party, including BIAC, TUAC, and member countries, who believe the Guidelines have been violated can request consultations with the Contact Points. If the discussions at this level do not resolve the issue between the parties, it can be passed to the OECD's Committee on International Investment and Multinational Enterprises (CIME, pronounced as "seemay"). CIME (located within the Directorate for Financial, Fiscal and Enterprise Affairs) was ultimately responsible for adjudication and development of the Guidelines. In response to disputes passed up by the National Contact Points, CIME responded by clarifying or interpreting specific language. This process of interpretation involved discussion within CIME as well as consultations with BIAC and TUAC. All CIME decisions required consensus among the member countries.

Dispute resolution under the Guidelines was not modeled on a traditional judicial model, for CIME's decisions had no retrospective applicability. Indeed, since the Guidelines were adopted as recommendations, they could not be

80. Guidelines, supra note 78, Chapter IX.

81. The Guidelines called on MNEs to

\$ respect the right of their employees to be represented by trade unions and other bona fide organisations and engage in constructive negotiations with them on employment conditions;

$\$$ provide assistance and information to employee representatives;

$\$$ provide information for a true and fair view of the performance of the enterprise;

$\$$ observe standards of employment and industrial relations not less favorable than those observed by comparable employers in the host country;

$\S \quad$ utilize, train and prepare for upgrading their labor force;

$\S$ provide reasonable prior notice of changes in operations, in particular on intended closures and collective layoffs;

$\$$ refrain from discriminatory practices in their employment policies;

$\S$ not exercise unfair influence over bona fide negotiations with employee's representatives;

\$ enable authorized representatives of their employees to conduct negotiations on collective bargaining or labor-management relations with management representatives authorised to take decisions on the matters at hand.

Id. at $13-14$. 
treated as binding standards. Perhaps surprisingly, given the formality of the process, CIME did not even make a judgment on the behavior of the companies in question. Instead it used the case to clarify the meaning of how a provision in the Guidelines should be applied in future cases. In a legislative context, the closest analogy to this practice would be if Congress continued creating legislative history after its passage of a statute. The logic behind this system is similar to that of the common law's clarification of doctrine in specific applications. Unlike the common law analog, however, CIME's interpretations were never binding once established and resulted in no penalties for violations.

Following the Guidelines' adoption in 1976, TUAC actively sought interpretation of the Employment and Industrial Relations Guidelines and brought a slew of cases resulting in over forty decisions by the end of the 1980s. TUAC's clear goal was to influence both MNE behavior and national laws. Although the results of these cases and others led to CIME decisions clearly promoting labor rights, ${ }^{82}$ these decisions largely fell on deaf ears at the national level. Given that the Guidelines provided no binding retrospective or prospective application and carried no sanctions in the case of violations, the lack of domestic response is unsurprising. Realizing the decisions were having little influence on government or MNE behavior, TUAC become less involved, bringing only four labor cases during the 1990s.

The Guidelines have been amended four times-in 1979, 1984, 1991, and 2000. In 1991 a new chapter was added on the environment. The most recent revisions, approved on June 27, 2000, were the result of lengthy consultations with a wide range of non-state actors and led to dramatic changes. No longer simply a clearinghouse for CIME, the NCPs were overhauled in the revisions to become active investigating and settlement authorities. Anyone may forward a complaint (known as a "specific instance") to the NCP, and the specific instance need not have occurred in the member state (that is, the Guidelines now apply to the global operations of MNEs based in adhering countries). Thus, for example, a Venezuelan-based subsidiary of an American MNE would be covered by the Guidelines. ${ }^{83}$ The NCP then investigates the details, decides whether the Guidelines have been violated and issues a report that names the company.

The NCPs' new role has been described by the OECD secretariat as a "soft whistle-blowing facility." " In the United States, the NCP is located in the State Department. The Australian NCP is in the Ministry of the Treasury, while

82. For case summaries, see Christopher R. Coxson, The 1998 ILO Declaration on Fundamental Principles and Rights at Work: Promoting Labor Law Reforms Through the ILO as an Alternative to Imposing Coercive Trade Sanctions, 17 DICK. J. INT'L L. 469 (1999); see also INTERNATIONAL ENCYCLOPEDIA ON LABOUR LAW AND INDUSTRIAL RELATIONS, VOLUME 6 (Roger Blanpain ed., 1985).

83. Although Venezuela would not have a National Contact Point in its government, the Procedural Guidance annex to the Council Decision on the Guidelines provides advice and guidance for the U.S. National Contact Point to follow in case of challenges in non-adhering countries. The actual coverage of the Guidelines could be larger still, since the General Policies chapter mentions subcontractors and suppliers of MNEs. See Guidelines, supra note 78 at Chapter II(10).

84. Interview with OECD secretariat in Paris, France (July 2003). 
Norway and several other countries have a tripartite NCP, including the Ministry of Foreign Affairs and Industry. Compared to the pre-2000 Guidelines, the more substantive Revisions have been extremely successful. As of December, 2003, the Guidelines had been adopted by thirty-seven countries, and sixty-four specific instances had been filed in twenty-one countries. ${ }^{85}$ Unlike the frustrating experience of toothless CIME decisions prior to the 2000 revisions, parties clearly believe that the potential benefits of bringing specific instances today are worth the expense.

A recent specific instance in Sweden illustrates how the revised Guidelines work in practice. The NCP in Sweden is administered by three ministriesIndustry, Justice, and Environment. In 2002, Friends of the Earth and ATTACK filed a specific instance against two Swedish companies' operations at the Ashanti Goldfields in Ghana. The letter launching the specific instance was accompanied by documentation alleging violations of the Guidelines. The NCP held meetings with the NGOs and the companies, visited the site, and requested the Swedish embassy in Ghana to investigate the allegations. In its report, the NCP concluded that the companies were too far removed from the mine operations to be held responsible under the Guidelines. The report's publication was accompanied by a press release. ${ }^{86}$ In another example, the Korean NCP investigated a specific instance in Sri Lanka of a Sri Lankan/Korean joint venture (half owned by the Korean company),

\section{which fired four workers for their union organization activities. Although the joint venture contract states that the Sri Lankan partner is in charge of labor-management, the Korean NCP recommended that the Korean company share "the responsibility as co-manager" and that the company "conform to the OECD Guidelines and resolve its labor disputes. ${ }^{87}$}

In contrast to the process prior to the 2000 revisions, NCP action ended the matter and CIME was not involved. Indeed, it is now expected that CIME will become involved only in the case of failure, when the national NCP is unable to resolve the issue. Indeed, of the over sixty cases since the revisions, only one has gone beyond the NCP to CIME. Instead, CIME now serves in largely an oversight capacity, following up with NCPs that have not reported their activities (another example of using peer pressure to promote compliance) and clarifying aspects of the Guidelines. In this role, CIME is assisted by BIAC and TUAC, which can request clarifications or interpretations of the text and procedural guidance. NGOs have a voice in this process through OECD-Watch, an NGO umbrella group created for this purpose.

The "Procedural Guidance" establishing the NCPs states that "NCPs will operate in accordance with core criteria of visibility, transparency, accessibility, transparency and accountability to further the objective of functional equiva-

85. Approximately two-thirds of the specific instances concerned company operations in nonadhering countries. OECD Guidelines for Multinational Enterprises: 2003 Annual Meeting of the National Contact Points, Report by the Chair at 9, at http://www.oecd.org/dataoecd/3/47/15941397.pdf.

86. Id. at $10-11$.

87. Id. at 10 . 
lence." ${ }^{88}$ In practice, approaches to transparency have varied significantly as NCPs seek to find the appropriate balance between confidentiality and openness. ${ }^{89}$ NCPs are also struggling to define their role in relation to more formal judicial processes. Ten of the twelve most active NCPs, for example, reported that "at least one of their specific instances involved business conduct covered by host country laws, regulations or administrative procedures. . [ [and that] it is quite common to use the specific instance procedure in parallel with legal regulatory or administrative procedures." 90

The revised content of the Guidelines in 2000 was not the only change of importance. From an institutional perspective, perhaps far more important was the revision process. Reflecting lessons from the MAI experience, the revision process was much more inclusive than ever before. Breaking from tradition, for the first time CIME created a truly public consultation process, actively seeking input from both outside the OECD and inside (from the Environment Directorate, for example, and from the OECD Working Party on Bribery and Corruption). The Chair of the OECD Working Party on the Review, Marinus Sikkel of the Netherlands, convened an informal consultation group of TUAC, BIAC and selected NGOs. Known as the Hague Process, Sikkel invited these groups to a brainstorming meeting in the Hague with the understanding that the participants spoke in a personal capacity. Before each subsequent meeting the group was given a draft of a paper prepared by Sikkel and OECD staff (but which had not yet been sent to governments). The last meeting in Amsterdam was expanded to include three members from TUAC, three from BIAC, three NGOs, Sikkel, and OECD secretariat staff, and government representatives from the United States, the United Kingdom, and Mexico. The Hague Process operated in many respects like a focus group. The members had no mandate to bind their organizations, but their reactions and creative drafting provided insights (and perhaps a buy-in) that would not otherwise have been apparent.

This draft then fed into a process that resembled notice-and-comment rulemaking. The OECD posted the draft text of the Guidelines on the web and in-

88. 2003 Annual Meeting, supra note 85, at 12-13.

89. The 2003 Annual Review notes, for example, that practices differ widely in relation to informing parties of the progress in handling specific instances, provision of information to non parties, publication of the fact that a specific instance has been raised, making statements while the specific instance is being considered, publication of the reasons for not agreeing to consider a specific instance, and the naming of parties to a specific instance.

Id. at 14 .

90. Id. at 14-15. The 2003 Annual Review notes that

NCPs differed in their response as to whether the fact that a specific instance concerned business conduct covered by legal, regulatory or administrative procedures would influence their approach to a specific instance. Nine experienced NCPs felt that if could or has already influenced decisions. For example, one experienced NCP was confronted with a specific instance that concerned business conduct that was also the subject of legal proceedings. In this situation, the NCP felt it could not proceed in dealing with the specific instance. Another experienced NCP felt that national legal, regulatory or administrative procedures would not affect their decision.

Id. at 33 . 
vited public comments. Comments were sent by businesses, labor unions, environmental groups, academic institutions, individuals, and non-member countries, and these, too, were posted on the web for all to see. A second draft text, influenced by these comments, was posted and subject to a similar round of public comment. $^{91}$

Although not surprising to those familiar with national administrative rulemaking procedures, this was unprecedented at the OECD. While secretariat staff who works with the Guidelines regard it as a great success, it is interesting to note that this process was not followed during development of the Common Approaches to Export Credits described in the preceding case study.

IV

\section{ADMINISTRATIVE LAW AT THE OECD}

These case studies provide empirical evidence to understand the role and development of administrative law at the OECD. In the context of global administrative law - the administrative law of international organizations - the OECD offers two important insights. The first concerns whether administrative law should apply to important OECD activities that are not traditionally considered lawmaking. The second explains why the OECD has adopted a decentralized model of administrative law.

\section{A. Administrative Law for "Not Yet Law"}

In the little that has been written on the OECD, it is often held up as a prime example of an organization that operates on the basis of cooperation and informal networks, relying on "soft law"-recommendations and guidelinesrather than hard rules. Anne-Marie Slaughter, for example, has described the OECD as a model for future international organizations, focusing on its ability to bring together many constituent interests for "transnational problem solving." 92 Her assessment rests on the growth of what she calls "transgovernmentalism"-cooperative problem-solving by global networks of subparts of the nation state. "These parts," Slaughter argues, "are networking with their counterparts abroad, creating a dense web of relations that constitutes a new, transgovernmental order .... [T]ransgovernmentalism is rapidly becoming the most widespread and effective mode of international governance." 93 By providing a forum for government officials and nongovernmental experts to meet and share research and experiences on cutting-edge policy issues, the OECD can frame the issues for future collective consideration, lay the groundwork for

91. CIME also formally invited the ILO to all Working Party meetings. See http://www1.oecd.org/media/release/nw00-27a.html.

92. Slaughter, supra note 13 , at 196.

93. Id. at $184-85$. 
agreement, and identify who shall provide the influential voices in the policy debate. ${ }^{94}$

Dick Stewart has described such activities of coordination and standard setting as "horizontal arrangements" of administrative law that

involve informal cooperation among national regulatory officials to coordinate policies and enforcement practices in areas such as antitrust, telecommunications, chemicals regulation, and transportation safety. Such coordination helps to reduce barriers to trade and commerce created by differing national regulations and to address transnational regulatory problems that exceed purely domestic capabilities. ${ }^{95}$

Recall that the OECD's committees, working groups, expert groups and conferences bring together approximately 40,000 government officials and experts annually. ${ }^{96}$ Apart from setting standards (such as the Test Guidelines) and negotiating Recommendations and Decisions, some of these gatherings inevitably coalesce into a core of identifiable groups of experts that influence the delineation of policy challenges and strategic analysis of how they should be resolved. ${ }^{97}$ These actions operate below the radar screen of what we normally consider to be "lawmaking" activities but may significantly influence agency activities. As Stewart notes, a horizontal network of agency officials

may agree informally to a common regulatory policy that is subsequently implemented domestically by participating U.S. regulators through rulemaking or enforcement actions. While these domestic implementing decisions are subject to U.S. administrative law procedures and judicial review, the underlying policy was adopted through extranational processes that are not. Moreover, in some cases there may be no formal domestic decision at all, but merely administrative exercise of discretion-for example, a decision not to enforce U.S. requirements against imported products because of

94. "International organizations provide the physical contact and aura of legitimacy that translate some of these potential transgovernmental coalitions into active ones... These coalitions form not only through contacts in the countries but sometimes through an active role by secretariat officials." Krause and Nye, supra note 5, at 337-38. Although an epistemic community need not be linked with a specific IGO or necessarily include government officials, this is often the case. See generally Peter M. Haas, Introduction: Epistemic Communities and International Policy Coordination, 46 INT'L ORG. 1 (1992).

95. Richard B. Stewart, Essay: Administrative Law In The Twenty-First Century, 78 N.Y.U. L. REV. 437, 455 (2003). This is reinforced by the observation of Krause and Nye that "With the growth of economic interdependence, more bureaucracies that were once considered domestic become involved in international affairs. Many bureaucracies and agencies of governments have similar interests. In some cases, the similarity of interests is greater across national lines than it is with competing domestic agencies and interests." Krause and Nye, supra note 5, at 337 (emphasis added).

96. http://www.oecd.org/dataoecd/15/33/34011915.pdf.

97. The influence can be indirect, as well:

As such practices [that is, patterns of regularized policy coordination] become widespread, transgovernmental elite networks are created, linking officials in various governments to one another by ties of common interest, professional orientation, and personal friendship. Even where attitudes are not fundamentally affected and no major deviations from central policy positions occur, the existence of a sense of collegiality may permit the development of flexible bargaining behavior in which concessions need not be requited issue by issue or during each period.

Robert O. Keohane and Joseph S. Nye, Transgovernmental Relations and International Organizations, 27 WORLD POLITICS 39, 46 (1974). This observation is equally true for nongovernmental officials. 
a prior informal agreement on functional equivalence or mutual recognition of regulatory standards. ${ }^{98}$

One could make a few word changes in this quote and it would describe exactly the Sixth Revision of the Common Approaches to Export Credits-an OECD agreement that was never formally approved by Council yet was adopted throughout the OECD. And this can happen quite often because of the OECD's inherent flexibility. Since its work program is decided by the member countries, it can transform its organizational dividing lines, procedures, and priorities in line with changing governmental concerns over complex, multilateral issues that require information creation and dissemination (such as labor standards and trade flows). ${ }^{99}$

And what about activities even farther removed from lawmaking? The OECD's importance as an international organization rests foremost on its technical expertise. It is best known for its research activities. While the OECD creates standards and, on rare occasions, makes law, most of the time it shapes ideas and marshals facts operating as a powerful consulting firm. These research activities have important impacts beyond the marshalling of information. In bringing experts together, the OECD creates international networks. In the role of transgovernmental problem-identifier and -solver, the OECD has the ability in some instances to create the debate and in many instances to channel the debate, fixing the contours of discussion over what is desirable and what is possible. ${ }^{100}$ The net effect can be a subtle but significant form of advocacy. As David Trubek has observed, the result is an "organization built around the idea of technical expertise that has had to confront the fact that the technical is the political.... It could be argued that this work is as, if not more, important than the more formal law making." 101 Yet beyond derestriction requirements prior to publication of OECD documents, there are no formal administrative procedures for research activities.

Consideration of the OECD's different forms of influence leads us to consider which, if any, administrative procedures and safeguards are appropriate for activities that influence and shape rules, but are not rulemaking processes. Put another way, for some international organizations, such as the WTO and E.U., we care about their administrative law because actions taken by these organizations can have regulatory-like effect in nation-states while supplanting domestic administrative law safeguards. But this does not seem to be the case for most of the OECD's activities, which fall more comfortably in the "not yet law" category.

98. Stewart, supra note 95 , at 456.

99. Of course, this also means that certain issues are not addressed, or are possibly avoided. For example, the ELSA Committee has not considered issues of female and child labor as seriously as at the World Bank, or labor market flexibility as seriously as at the International Labor Organization.

100. Keohane and Nye, supra note 97, at 53-54.

101. Comments from David Trubek to James Salzman, Comments on Salzman's OECD Chapter 2/17/04, prepared for NYU workshop (2004) (unpublished manuscript) (on file with author). 
Instead, perhaps we should be more concerned over the interplay between domestic administrative law procedures and actions at IGOs that we tend not to think of as lawmaking, but that influence agency action. There are already procedures in place at the OECD to ensure accuracy of information, but Trubek, among others clearly has more in mind. Even if one ignores the OECD's occasional role as lawmaker and standard-setter, its activities as a transgovernmental actor and knowledge-creator make it an important power center. Serious consideration of global administrative law therefore must also examine the outer limits of administrative process in the international arena.

Put most broadly, then, how should the administrative safeguards of transparency, responsiveness, and accountability apply to the knowledge-creation and management of informal horizontal networks in international organizations? One could imagine administrative procedures that increased the transparency of the OECD's choice of outside experts to draft reports-experts who commented on the reports, whether an adequate range of views has been considered or reflected in the research, or, indeed, how the research topic was chosen. Arguments for such procedures are premised on the insight that research both is political and has political implications that can affect domestic agency activities. One needs to be careful, however, that procedural safeguards do not overburden the exchange of ideas and information. After all, it may well be the very lack of safeguards and the friction they would create to the exchange of ideas that makes such networks effective in the first place. Nor is it clear what type of procedural safeguards would be appropriate. Unlike the definite and discrete character of notice-and-comment rulemaking, for example, knowledge creation and networking are, by definition, expansive, organic, and dynamic endeavors. A fruitful avenue for future research might therefore examine how administrative law addresses information gathering and networking activities at the domestic level, and assess whether these practices would be appropriate at the international level. This issue is difficult but important, and deserves closer consideration.

B. The Evolution of Decentralized Administrative Law at the OECD

In assessing the role of administrative procedures and safeguards at the OECD, one must keep in mind that traditionally these have not been issues that anyone cared about. When I worked at the OECD's Environment Directorate a decade ago, for example, we would sometimes discuss engagement with NGOs on specific issues, but the general topic never came up. That is why the MAI experience was such a shock. It drew the OECD into intense public scrutiny and forced staff within the OECD to recognize the importance of including civil society. Not only was the OECD experiencing its first significant public criticism, but its procedures were being criticized by NGOs and, subsequently, by governments. Those in the secretariat at the time felt blindsided and bloodied. Thus the MAI story is a cautionary tale-showing how the choice of an administrative process contributed to the implosion of the MAI negotiations. 
In assessing the failure of the MAI negotiations, three basic lessons were clear to the OECD secretariat. First, substance matters. Although regarded by the secretariat as simply a harmonization exercise of existing BITs, the MAI would have changed the balance of power in FDI, making it harder for host countries to restrict foreign investment activities. This was why efforts to address investment had failed in the Uruguay Round. Second, membership matters. The failure to negotiate an investment agreement for the world during the Uruguay Round led some proponents, particularly the United States and France, to seek a more welcoming forum. The like-minded, wealthy nations of the OECD emerged as an obvious candidate for such a "build it and they will come" strategy of treaty negotiation. Third and most important, the administrative process matters. The traditional closed-door approach of the OECD during the negotiations and lack of meaningful engagement with civil society engendered suspicion and made the OECD an easy target because it could not defend itself by revealing what was actually happening around the table. ${ }^{102}$ If the OECD was not conscious of civil society's power before the MAI, it certainly was afterwards. What makes the subsequent case studies so interesting is that they demonstrate very different reactions to these lessons.

At first glance, the development of the Common Approaches on Export Credits seems to have gained nothing from the MAI experience. The MAI and Common Approaches negotiations looked nearly identical. Negotiations took place behind closed doors. Documents were restricted. Meetings with civil society were infrequent and more in the manner of information dissemination than discussion. Perhaps this should have been expected, for the Common Approaches negotiations involved national civil servants in many cases from the same ministries as the MAI.

In looking deeper, though, the MAI debacle did sensitize the OECD to administrative law values, for a fundamental shift had taken place by the time the Common Approaches negotiation got serious. In early discussions, OECD staff made it clear to member states not only that consultations with civil society needed to take place (which was unusual in itself) but, more fundamentally, that responsibility for engagement lay first with the member states, not with the OECD. Although consultation burdens were formally shared by the OECD and member states both in Paris and in the national capitals, the net result effectively delegated most of the consultation and transparency responsibilities to the member states. This transformed what would otherwise have been a solely international negotiation among like-minded agencies into a broader discussion with non-state input.

This could not have been a greater contrast to the revision of the MNE Guidelines, taking place at the same time. For all effective purposes, this was about as close to notice-and-comment rulemaking as one can get in the interna-

102. It is not at all clear that different administrative law procedures have led to a successful MAI negotiation, given the substantive disagreements over the text, but the administrative process certainly helped fan the public outrage over the negotiations that ultimately doomed them. 
tional arena. A representative focus group tackled the issues informally, hammering out a draft that was then widely disseminated with a request for comments. The revised version was then publicly posted again. And make no mistake, the Guidelines involved a lot more sectors of civil society than the Common Approaches. The member states negotiating the Common Approaches knew of the Guidelines' revision process but chose not to follow it.

Perhaps most interesting in terms of institutional learning, the most successful and effective process for civil society engagement, the MAD system, has not been copied anywhere else in the OECD. The process of creating a role for the formal engagement of non-state experts, routinely open meetings, and derestricted documents stands in stark contrast to the MAI and Common Approaches processes. Yet these procedures have not been followed by other OECD negotiations. Perhaps the technical complexity of standard setting makes this a difficult model to adopt elsewhere, but surely the guiding principles of transparency and peer review are transferable.

Taken together, these observations suggest that the OECD does not have "an administrative law" for the organization. Indeed, the decision seems to have been made at the highest levels of the OECD not to establish an organization-wide set of principles, rules, and processes concerning the transparency, accountability, and engagement of OECD activities. As the case studies demonstrate, these vary enormously throughout the organization. In fact, in contrasting the cases of the MAD system, the Common Approaches and the MNE Guidelines, it would be hard to come up with three more distinct methods of addressing transparency, responsiveness, and accountability. This all could have changed after the MAI saga, but the OECD Council chose to retain the organization's decentralized manner of operations, effectively rejecting the topdown Operational Directive approach of the World Bank. In practice, this has meant leaving it up to each Directorate (indeed to each division) how best to ensure administrative process safeguards.

\section{$\mathrm{V}$ \\ CONCLUSION}

The obvious question that follows is why there are such radically different administrative processes at work within the same organization. There are at least three explanations worth considering. The first rests in the dynamic of credibility and effectiveness. In other words, for the Common Approaches to work, the OECD Recommendation needs to be adopted by the national ECAs. In terms of lobbying and politics, it would be nice if non-state actors supported the final result, but this is by no means necessary. For the Guidelines to work, by contrast, civil society must be willing to file specific instances. They have to accept both the legitimacy and the effectiveness of the process. Otherwise the NCPs will become dormant, as occurred in the 1990s when labor groups realized the CIME decisions were impotent. Similarly, while the MAD system ultimately depends only on the acceptance of test results by national agencies, the 
credibility of the system rests firmly on its acceptance by industry and NGOs. There are few places in the world where animal welfare activists and chemical company toxicologists sit at the same table and seriously work together.

The second reason there is not a uniform administrative law in the OECD lies in membership_not national membership, but directorate membership. Each directorate's choice of process for working with civil society depends on what is deemed necessary for credibility and effectiveness in a particular setting. Or, to put it more accurately, the member state delegates in each directorate have different priorities and manners of operation, indeed different worldviews. It is not surprising that the most open and responsive of all the case study processes analyzed, the MAD system, is run by a part of the organization, the Environment Directorate, with the most experience in working with NGOs. After all, the member state delegates making decisions in the Environment Directorate already have extensive experience interacting with NGOs in their own countries on a regular basis. The MAI and Common Approaches, by contrast, were negotiated and directed by officials from treasury ministries-agencies hardly known for their efforts to engage civil society at a domestic level. So why would one expect anything different when the same people are operating at the international level? This explanation suggests that national delegates seek to reproduce familiar institutions and processes at the OECD.

The effect of the directorate's relative familiarity with NGOs also sheds light on a common issue in other international organizations - the relative influence of secretariats versus government representatives in determining administrative procedures. ${ }^{103}$ From the cases studied, the OECD secretariat seems to play a relatively minor role in determining institutional processes. Yet given the traditional role of the OECD, the power of government delegates is not surprising. Perhaps more than any other IGO, the OECD is a member-statedriven organization, prioritizing its work program every year based on a vote of member state preferences and working toward consensus in its day-to-day activities.

The third explanation for the OECD's flexible approach relies on path dependence. The OECD has multiple administrative law processes because its growth has been organic, extending into areas in which administrative procedures are needed in an opportunistic rather than a planned manner. There was not an organization-wide administrative law at the time of the organization's creation because none was necessary for implementing the Marshall Plan. As the organization grew, creating new directorates to address fields of interest to member states, the organization remained decentralized. Much as America's

103. Benedict Kingsbury has described the question as

whether the operation of OECD regulatory processes is the direct expression of the common sensibility of national government delegates in their network ... or alternatively whether the design of these regulatory processes interposes institutional features, e.g., a layer of fairly independent international bureaucrats between the network and the decisions.

E-mail from Benedict Kingbury to James Salzman, Conversation with Jim Salzman re Global Ad Law paper, September 18, 2003 (on file with author). 
fifty states have been termed "laboratories of democracy," free to develop their own policies and procedures on matters of local concern, so, too, the OECD Council gives great discretion to each directorate to determine how best to run its affairs. The OECD likely will never develop a uniform approach for setting standards, negotiating recommendations, or sanctioning noncompliance for the simple reason that different directorates have different priorities, constituencies, and manners of dealing with these issues. ${ }^{104}$

It is worth remembering, as well, that administrative processes are dynamic. The reaction of civil society to OECD administrative law developments has been as opportunistic as any initiative within the organization. Witness the creation of OECD-Watch, the group addressing the OECD Guidelines, ECA Watch, addressing the ECA negotiations, and ICAPO, addressing the MAD process. These NGOs were created for the sole purpose of engagement with the OECD on specific issues, seeking to replicate the influence exercised by the more formal TUAC and BIAC for decades. Administrative law at the OECD is thus both decentralized and dynamic, changing issue by issue both within and outside the organization.

104. Widely different views on the appropriate transparency, responsiveness, and accountability of government action are not only held across different ministries but across different governments, as well. Thus the United States holds starkly different views on appropriate administrative safeguards compared to Japan, Mexico, or Turkey, yet all are OECD Member states. 